\title{
Rinoplastia experimental com enxerto autógeno de costela em cães*
}

\author{
EDUARDO DE BASTOS SANTOS JUNIOR
}

\author{
Antônio de Pádua Ferreira da Silva Filho (Orientador - UFRGS) \\ Emerson Antônio Contesini (Co-Orientador - UFRGS)
}

Banca: Carlos Afonso de Castro Beck (UFRGS), João Antônio Tadeu Pigatto (UFRGS), Ney Luis Pippi (UFSM)

\begin{abstract}
A rinoplastia é a cirurgia plástica da cavidade nasal, que é muito difundida na medicina humana por motivos estéticos. Os animais possuem doenças que exigem cirurgia na cavidade nasal e na espécie canina pouco foi estudado com relação a rinoplastia. Algumas lesões causadas por traumatismo, tumores, fungos e reações inflamatórias crônicas, podem causar destruição de tecidos, sendo necessária a reconstituição do local. O uso de enxertos em animais é bastante difundido, principalmente os ósseos. No presente trabalho estudou-se o uso de costela autógena para correção de defeito criado em osso nasal em cães. O experimento foi realizado na Faculdade de Veterinária da Universidade Federal do Rio Grande do Sul. Utilizou-se 15 animais, separados em três grupos de pós-operatório onde após 30, 60 e 90 dias finalizavam-se seus acompanhamentos. Cada grupo era composto de quatro animais enxertados e um animal controle onde se utilizava o material do próprio defeito criado para coaptação. Os animais foram acompanhados clinicamente, a integração do enxerto foi avaliada com exames radiográficos obtidos a cada 15 dias até o final de seu acompanhamento pós-operatório. A histopatologia foi realizada no último dia de acompanhamento, conforme a distribuição dos animais nos grupos. Os resultados mostraram que a técnica cirúrgica é de fácil execução e possui praticidade em seu uso. O emprego da costela foi suficiente para cobertura de todos defeitos criados. O efeito estético foi excelente. Os exames radiográficos comprovaram a integração do enxerto e a avaliação histopatológica evidenciou a presença de células compatíveis com a viabilização da técnica proposta. Sendo possível então o uso de enxerto autógeno de costela para reconstrução de defeito criado experimentalmente em dorso nasal de cães.
\end{abstract}

Descritores: rinoplastia, cão, enxerto, costela. 


\title{
Experimental rhinoplasty using autogenous rib graft in dogs ${ }^{* *}$
}

\author{
EDUARDO DE BASTOS SANTOS JUNIOR
}

\author{
Antônio de Pádua Ferreira da Silva Filho (Adviser - UFRGS) \\ Emerson Antônio Contesini (Co-Adviser - UFRGS)
}

Committee: Carlos Afonso de Castro Beck (UFRGS), João Antônio Tadeu Pigatto (UFRGS), Ney Luis Pippi (UFSM)

The rhinoplasty is a plastic surgery of nasal cavity; it's very popular in human medicine by aesthetic reasons. The animals have diseases that need surgery at nasal cavity and in canine specie a few was study about rhinoplasty. Some injuries as trauma, tumor, fungus and chronic inflammatory reactions, can destroy tissues and be necessary local rebuild. The use of grafts in animals is very widespread, principally bone grafts. The present work studied the use of autogenous rib to correct a maked defect in nasal bone in dogs. The experiment was realize at Faculdade de Veterinária da Universidade Federal do Rio Grande do Sul. Were used 15 animals, separated in three postoperated groups. After 30,60 and 90 days their monitorament have been finished. Each group was compound by four grafted animals and a animal control. Where used the same material of the created defect to make the correction. The animals were clinically observed, the graft integration was value with radiological exam taked every 15 days until the end of the post operate monitorament. The histopathology was realized in the last day of accompany, according to the distribution of the animals in groups. The results show that the surgical technique is easy to perform and have practice in the use. The rib used was enough to correct all created defects. The aesthetic result was excellent, the radiological exams prove the graft integration and the histological evaluation shows the presence of compatible cells, making the technical proof proposed viable. So the use of autogenous graft to correct a created experimental defect in dog nasal dorsum is possible.

Key words: rhinoplasty, dog, graft, rib. 